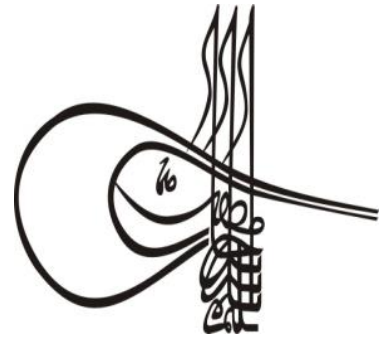

Received/Geliş: 03.04.2019

\section{Turkish Studies Historical Analysis \\ Volume 14 Issue 2, 2019, p. 413-428 \\ DOI: 10.29228/TurkishStudies. 22460 \\ ISSN: 2667-5552 \\ Skopje/MACEDONIA-Ankara/TURKEY}

Research Article / Araştırma Makalesi

Article Info/Makale Bilgisi

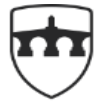

INTERNATIONAL BALKAN UNIVERSITY

EXCELLENCE FOR THE FUTURE IBU.EDU.MK

Go Report Dates/Rapor Tarihleri: Referee 1 (15.04.2019)-Referee 2 (20.04.2019)- Referee 3 (25.04.2019)

This article was checked by iThenticate.

\title{
XIX. YÜZYILIN BAŞLARINDA OSMANLI-İRAN İLIŞKİLERİ (1800-1806)
}

\author{
Abdurrahman ATEŞ*
}

\begin{abstract}
öz
XIX. yüzyıl başlarında Osmanl1-İran ilişkilerinde, İran'ın Hoy Hanı Cafer Kulu Han'in Osmanlı Devleti'ne, Kuzey Irak'ta Osmanlı tebasından Baban Mutasarrıfı Abdurrahman Paşa'nın da İran'a iltica etmesi ile Vehhabilerin Kerbela'ya baskınları yanında Bağdad Valisi Ali Paşa'nın Osmanlı Hükümeti'nin emrini almadan İran'a karşı harekete geçmesi olayları etkili oldu.

Osmanl1-İran ilişkileri, vuku bulan bu olaylar sebebiyle, zaman zaman gerginleşmiş hatta bir ara fiili çatışmaya dönüşmüşse de, genel itibariyle her iki devlet de (bilhassa Osmanlı Devleti), iki ülke arasında husumete yol açan meseleleri sulh yoluyla halletmeye çalışmışlardır. Bu çalışmada, XIX. yüzyıl başlarında Osmanl1-İran siyasi ilişkileri (18001806) ele alınarak, kaynakların verdiği bilgiler nispetinde, bazı değerlendirmeler yapılmaya çalışılmıştır.

Konunun ana mihveri çerçevesinde, giriş kısmında Ağa Muhammed Han'ın İran'da Kaçar Devleti (1795-1925)'ni kurmas1, onun yerine yeğeni Feth Ali Şah (1797-1834)'ın geçmesi ile XIX. yüzyıl başlarında İran ve Osmanlı Devleti'nin genel durumları hakkında kısaca bilgi verilmiştir. Ardından XIX. yüzyıl başlarında Osmanlı-İran ilişkilerine tesir eden, İran'ın Hoy Hanı'nın Osmanlı topraklarına, Osmanlılar'ın da, Baban mutasarrıfinın İran'a iltica etmeleri, Vehhabilerin Kerbela baskınları ve Bağdad Valisi Ali Paşa'nın İran'a sefer açması hadiseleri, derli-toplu olarak tasvir edilmek suretiyle bir sonuca gidilmeye gayret edilmiştir.
\end{abstract}

Anahtar Kelimeler: Osmanl1-İran İlişkileri, Osmanlı Devleti, Bağdad, Kuzey Irak, İran. 


\title{
OTTOMAN-IRANIAN RELATIONS AT THE BEGINNING OF THE XIXTH CENTURY (1800-1806)
}

\begin{abstract}
The events which were effective in Ottoman-Iranian relations at the beginning of the XIXth century appeared to be taking refuge of Jafar Qoli Khan, Iranian Khan of Khoy in the Ottoman State, and conversely, of Abdurrahman Pasha, an Ottoman subject and Possessor of Baban of Northern Iraq, in Iran; the Wahhabi Sack of Karbala; and Ali Pasha, Governor of Baghdad, taking action against Iran without receiving an order from the Ottoman government.

Due to the said events, Ottoman-Iranian relations, although occasionally becoming strained, even turning into an armed conflict sometime, both states (especially the Ottoman Government) tried to settle the disputes that led to hostility between the two countries by peaceful means. In this study, Ottoman-Iranian relations at the beginning of the XIXth century are handled and certain evaluations are attempted as far as the facts provided by sources allow.

Within the framework of the subject matter, brief information has been given in the introduction about the establishment of the Qajar State in Iran by Agha Mohammad Khan (1795-1925), his replacement by his nephew Fath Ali Shah (1797-1834) 's XIX, and general situation of Iran and Ottoman Empire at the beginning of the 18th century. Later, the events which influenced the Ottoman-Iranian relations at the beginning of the XIX th century, namely, taking refuge of Iranian Khan of Khoy in the Ottoman territories, and conversely, of an Ottoman subject and Possessor of Baban, in Iran; the Wahhabi Sack of Karbala; and launching of a campaign by Ali Pasha, Governor of Baghdad, against Iran are concisely discussed and conclusions are attempted.
\end{abstract}

\section{STRUCTURED ABSTRACT}

Having ended the power struggles that started in Iran in 1779, it was the Ağa Muhammed Han who established the Kaçar Turkmen State towards the end of the 18th century, re-establishing the political unity in this country. Following his assassination in June 1797, Feth Ali Shah took the position of Shah of Iran, who was his nephew. In the early years of Feth Ali Şah's long-lasting rule, Sultan 3rd Selim was on the Ottoman throne. During these two emperors or at the beginning of the 19th century, Britain, France and Russia gradually increased their influence in both the Ottoman Empire and Iran. In their relations with the colonialist European states, both states had to follow a policy of equilibrium, sometimes based on one or the other.

The first of the agents that influenced the Ottoman-Iranian relations at the beginning of the 19th century was that Dumbuli Cafer Kulu Khan, who was the Khan of Hoy suburb, took refuge in the Ottoman lands. Following the death of Aga Muhammad Khan, Feth Ali Shah's uncle, Sadik Khan-i Shikaki in has revolted South Azerbaijan. Cafer Kulu Khan from the Dumbuli tribe played an important role in 
the quashing of this rebellion. Consequently, Feth Ali Shah gave the administration of Tabriz and Hoy suburb to Cafer Kulu Khan. However, then Cafer Kulu Khan rebelled to establish an independent administration in Hoy suburb. Upon the rebellion of Cafer Kulu Khan, Feth Ali Shah marched to South Azerbaijan. Having heard that Shah was marching towards him, Cafer Kulu Khan escaped from Hoy suburb and crossed the Ottoman-Iranian border and fled to the Ottoman Empire. The Iranian Government demanded that Rebel Cafer Kulu Khan be killed in the the Ottoman lands or returned to Iran or expelled from the Ottoman territories. In response to the request of the Iranian Government, the Ottoman Government did not give the right of accupancy to the refugee Cafer Kulu Khan in the Ottoman country and decided to return him to the Iranian government by continuing the peace policy that they followed since the mid 18th century.

Another important force that influenced Ottoman-Iranian political relations at the beginning of the 19th century was the raids performed by the Wahhabis on Karbala. On May 13, 1802, Wahhabi forces raided on Karbala at a time when Shiites were making a mourning ceremony. According to the sources, the Wahhabi forces killed a Shiite community whose number ranged from two thousand to five thousand, and they plundered and looted the city. They destroyed the grave of Hussein, taking all the precious things such as the gold, silver, etc. in the tomb and returned to Deryeiyye.

One more factor affecting the Ottoman-Iranian relations at the beginning of the 19th century was the happenings by the tribes and tribesmen who lived on the Ottoman-Iranian border (Northern Iraq). Following the Abaza Ali Pasha's was appointment to the governorship of Baghdad, people of Bilbas, who were actually belonged to the people of Ottomans; Suleiman tribe of Caf-1 Suleimaniyah Sanjak, living a nomadic life like staying Ottoman lands and visiting Iranian lands, caused disturbances. The Bilbas poeple, in the period we are currently talking about, led to the turmoil of confusion by the passing through the Ottoman lands into the Iranian territory. This literally caused the Iranian Government's complaint so that the governor of Baghdad, Ali Pasha himself marched on the tribe of Bilbas. He made them obey.

Later on, Ali Pasha marched upon Abdurrahman Pasha, the owner Baban province, who also cause turmoil. Ali Pasha defeated Abdurrahman Pasha in the fight that took place in Derbend. Ali Pasha returned to Baghdad in September 1805 by sending Halid Pasha to the Baban Sanjak and Suleyman Pasha to the village Sanjak. After his defeat in Derbend, Abdurrahman Pasha, who escaped, crossed the Ottoman-Iranian border with the tribes attached to him. Abdurrahman Pasha took refuge in Iran and asked for help from the Iranian Shah.

In addition to the fact that the Hoy Khan who fled from Iran to the Ottomans and the owner Baban who escaped from the Ottoman lands to Iran were rulers, they were also tribal lords. An agreement signed between the two states on 4 September 1746 due to that fact the tribal lords on the Ottoman-Iranian border violated the Ottoman-Iranian border, passing through both Iranian and Ottomans lands and leading desertion events. Although there were strict provisions for the return of the fugitives back to the parties, the issue could not be resolved. 
Therefore, it is understood that border violations continued in the early 19 th century.

The raid of Vahhabis on Karbala residing in the Ottoman lands in 1802 shows the fact that the Wahhabis strengthened and became a threat for the Ottoman Empire from the south. However, it is seen that this issue was settled in peace, as the Ottoman Government took the required measures in the relations with Iran in the sacred centers of the Shiites in Iraq. Without taking any order from Sublime Porte, Ali Pasha, the governor of Baghdad, declared war on Iran on the eve of the Ottoman-Russian (British War - December 1806). This means that the Ottoman central authority is now weakened. It is also revealed that there is a great authority gap in Baghdad (Iraq), one of the most important provinces in the Ottoman administration. It is also observed that the Ottoman government referred the issues related to Iran to the state governors on the Ottoman-Iranian border in the early nineteenth century, and it is even noticed that there was animosity among some border governors.

Considering this short assessment we have done up to now, it can be said that the Ottoman-Iranian political relations became tense from time to time due to incidents in the border region in the early 19th century and even the relations turned into an actual conflict. However, in general, the Ottoman and Iranian states sought to settle the issues that led to hostility through peace. In particular, it is seen that the Ottoman Government made the utmost effort to keep the relations going strongly with the Iranian State by constantly emphasizing the agreements made between the two countries in the solution of the issues. The Ottoman statesmen of the period followed a strategy for the continuation of the peace process that started with the treaty in September 1746 . We believe that this situation is extremely reasonable and accurate.

In short, the Ottoman-Iranian relations in the early 19th century have been influenced by the issues inside the Ottoman Empire such as the political, economic, military, etc., and fighting with the hostile countries like France, England and Russia outside the country borders. Taking the issue from the Iranian side, it is clearly visible that the relations were influenced by the fact that Iranian State was at war with the Russians in the South Caucasus during this period.

Keywords: Ottoman-Iranian relations, Ottoman Empire, Baghdad, Northern Iraq, Iranian.

\section{GİRIŞ̧}

Ağa Muhammed Han (1795-1797), XVIII. yüzyılın ikinci yarısında İran coğrafyasının mühim bir kısmında hüküm sürmekte olan Zend Hanedanı'nın iktidarına son vermek suretiyle, aynı yüzyılın sonlarına doğru bu ülkede, Büyük Selçuklular, Harzemşahlar, Timurlular, Kara-Koyunlular, AkKoyunlular, Safeviler ve Avşarlar'dan sonra yeniden Türkmen hakimiyetini tesis etti.

Esterabad Kaçarları'nın “Aşağı Baş” kolunun "Koyunlu” obasından Muhammed Hasan Han'ın oğlu olan Ağa (Aka) Muhammed Han, Mart 1779'da Lurlu Kerim Han Zend'in ölümü üzerine, uzun bir süreden beri rehin bulunduğu, Şiraz'dan kaçtı. Kuzeye Rey bölgesine gelip, mevcut siyasi 
ortamdan da istifade ile, Kaçar Türkmen Devleti'ni kurma yolunda mücadeleye başladı. Kardeşleriyle ve Kerim Han Zend'in ölümünün ardından birbirleriyle taht kavgasına başlayan Zend Hanedanı üyeleriyle mücadele edip, bu zorlu mücadelede başarılı oldu. Ülkedeki Zend Hanedanı'nın iktidarına 1794 'te kati olarak son verdi.

Ağa Muhammed Han, Tahran'1 1786 yılında devletinin başkenti yapıp, 1779 yılından itibaren on beş yıldan fazla süren mücadelesinde İran'ın büyük bir kısmı ile Kuzey Azerbaycan'da tam bir hakimiyet kuramamakla birlikte Güney Azerbaycan'1, Doğu Gürcistan (Tiflis)'1 ele geçirdi. Böylece o, İran'ın siyasi birliğini temin ederek, Kaçar Türkmen Devleti (1795-1925)'ni kurdu. Ancak ne var ki, bilhassa son derece teşkilatçı, mücadeleci, güçlü bir karaktere sahip olduğu görülen Ağa Muhammed Han, II. Güney Kafkasya harekatı esnasında Karabağ Türkmen Hanlığı'nın merkezi Şuşa'yı zapt etmesinden hemen sonra, şahsi hizmetinde bulunan ve idam cezasına mahkum ettiği üç hizmetçisinin 17 Haziran 1797 (21 Zilhicce 1211) gecesi düzenlediği bir suikastla, ordugahında öldürüldü. ${ }^{1}$

Ağa Muhammed Han'ın öldürülmesi ile yerine yeğeni (Ağa Muhammed Han'ın kardeşi Hüseyin Kulu Han-1 Cihansuz'un oğlu) aynı zamanda veliahdı ${ }^{2}$ ve Fars valisi Feth Ali Şah (Baba Han) ${ }^{3}$ Ağustos 1797'de tahta çıktı (Razi, 1375: 486; Yazıc1, 1995: 451). Feth Ali Şah (1797-1834)'1n hükümdarlığının ilk yılları amcası Ağa Muhammed Han'ın ölümünün ardından ülkede çıkan karışıklıktan istifade ile çıkan isyanları bastırmakla geçti. Nitekim Feth Ali Şah, amcası Ağa Muhammed Han'ın öldürülmesinden sonra, onun hazinesine el koyup, tahtı ele geçirmek gayesiyle başkent Tahran üzerine yürüyüp Kazvin'e kadar ilerleyen Azerbaycan hanlarından Sadık Han-1 Şikaki, Zend Hanedanından Zeki Han Zend'in oğlu Muhammed Han (Basra'dan İran'a geçmiştir) ile kardeşi Fars valisi Hüseyin Kulu Han ve Meşhed'i zapt eden Nadir Şah (1736-1747)'ın torunu Şahruh'un oğlu Nadir Mirza'nın isyanlarını bastırdı (Sykes, 1915: 393-394). Feth Ali Şah, kayda değer bu önemli isyanları bastırmasını müteakip, ülke genelinde saltanatını sağlamlaştırdı. Ancak onun döneminde İran, giderek sömürgeci İngiltere, Fransa ve Rusya'nın rekabet sahası haline geldi. O sebeple Kaçar Şah'1 bazen bu devletlerden birine, bazen de diğerine dayanarak denge politikası takip etmek suretiyle varlığını sürdürdü (Aka, 2002: 854; Yazıc1, 1995: 451; Razi, 1375: 488-489). İran'da durum bu meyanda iken XIX. asır başlarında Osmanlı Devleti de, dahili ve harici pek çok mesele ile karşı karşıya kaldı (Uluerler, 2015: 350).

\section{Osmanlı - İran Siyasi İlişkileri (1800 - 1806)}

Feth Ali Şah'ın İran'da şahlığının ilk yılları, Osmanlı devlet adamlarından Sultan III. Selim (1789-1807) zamanına tekabül etmektedir. Osmanlı Hükümeti, bu devrede İran'a karşı takip ettiği dış politikada, Ağa Muhammed Han'ın öldürülmesinden sonra, bu ülkenin içine düştüğü karışıklıktan faydalanma yoluna gitmediği görülmektedir. Zira Osmanlı Hükümeti, Feth Ali Şah'ın şahlığını henüz tasdik etmemekle 4 beraber İran'daki gelişmeleri dikkatle ve ihtiyatla takip ederek, Osmanlı Devleti'ne zarar gelmemesi için iki ülke arasında daha önce imzalanan barış antlaşmalarıyla başlayan barış sürecini devam ettirmek istiyordu. ${ }^{5}$ Esasen bu sıralarda Osmanlı Hükümeti, bir yandan 1792'de Rus Harbi'nin bitimiyle başlayan sslahat hareketlerini (Nizam-1 Cedid) genişletmeye gayret ederken, diğer

\footnotetext{
${ }^{1}$ İran'da Kaçar Devleti'nin kurucusu Ağa Muhammed Han hakkında geniş bilgi için bkz. J.R. Perry, “Aga Muhammed Khan Qajar”, Encyclopadia Iranica, c.I, California 1988, s. 602-605; Emine Pakrevan, Ağa Muahmmed Han Kacar, Tahran 1951, s. 23 vd; Faruk Sümer, “Ağa Muhammed Şah”, T.D.V.I.A., c.I, İstanbul 1988, s. 455-456.

${ }^{2}$ Avşar Hükümdarı Ali Şah (Adil Şah), Ağa Muhammed'i 1748'de muhtemelen 7-8 yaşlarında iken hadım ettirdiği için Ağa Muhammed Han'ın çocuğu yoktu. Bkz. F. Sümer, a.g.m., s. 455.

${ }^{3}$ Feth Ali Şah'ın ismi Osmanlı Arşiv vesikalarında bazen "Baba Han”, bazen "Baba Han Serdar”, bazen de "Baba Han Şah" şeklinde geçiyor. Mesela bkz. B.O.A., Hatt-ı Hümayun, D. Nr. 161, G. Nr. 6700; Keza bkz. B.O.A., Hatt-ı Hümayun, D. Nr. 160 G. Nr. 6680-B; D. Nr. 160, G. Nr. 6679-A.

4 “...canib-i saltanat-1 seniyyelerinden dahi şahlığı tasdik olunmak ümidiyle sefir-i merkumu Dersaadet'e göndermiş... henüz taraf-1 Devlet-i Aliyye'lerinden şahlığı musaddak olmadığından...” B.O.A., Hatt-ı Hümayun, D. Nr. 161, G. Nr. 6720.

5 “...Devlet-i Aliyye-i da'imü'l- karar ile Devlet-i İran beyninde mün'akıd olan esas-1 sulh u salahın esbab-1 resaneti ale'ddevam matlub-1 kat'iyy-i şahane idüğinden ...” B.O.A., Hatt-1 Hümayun, D. Nr. 161, G. Nr. 6721-F.
} 
taraftan da bilhassa Balkanlarda ortaya çıkan güçlü ayanlarla (Pazvandoğlu, Tirsiniklizadeler vb.) ve Osmanlı kaynaklarında Dağlılar (Kırcalılar) denilen eşkıya çetelerini ortadan kaldırmakla meşguldü (Uzunçarş111, 2010: $3 \mathrm{vd}$ ).

Sultan III. Selim (1789-1807) zamanında Osmanlı Devleti’nin karşı karşıya kaldığı, diğer bir önemli mesele de Napolyon Bonapart'ın Mısır'ı işgali oldu. Nitekim o yıllarda yıldızı parlayan Napolyon Bonapart, İngiliz-Fransız sömürge mücadelesinin bir uzantısı olarak Temmuz 1798'de Mısır'1 işgal etti (Karal, 1983: 27; Beydilli, 2009: 423). Osmanlı Devleti, Fransa'ya karşı Aralık 1798'de Rusya, Ocak 1799'da İngiltere ile yaptığı ittifak antlaşmalarıla nihayet İngiliz ve Ruslar'ın yardımıyla Haziran 1802'de Fransa'y1, Mısır'ı terk etmeye mecbur etti. Ancak Fransa'ya karş1 Rusya ve İngiltere ile yaptığı ittifaklar karşı1lı̆ında onlara yeni tavizler vermek zorunda kaldı. O sebeple dış politikasında önemli değişiklikler yaparak, devletlerarası ilişkilerinde "denge politikası"nı kabul etmek zorunda kaldı. Bu politika da Osmanlı Devleti’nin ileride yeni iç ve dış meselelerle karşı karşıya kalmasına yol açtı (Uçarol, 2000: 84 vd).

XIX. yüzyılın başlarında veyahut Sultan III. Selim (1789-1807) döneminde Osmanl1-İran ilişkilerine tesir eden amillerden ilki, Hoy Hanı Dumbuli Cafer Kulu Han'ın Osmanlı topraklarına sığınmasıdır.

\section{I- Hoy Hanı Cafer Kulu Han'ın Osmanlı Devleti'ne Sığınması}

Feth Ali Şah'ın, amcası Ağa Muhammed Han'ın ölümünün ardından Güney Azerbaycan'da isyan eden Sadık Han-1 Şikaki isyanının bastırılmasında Dumbuli aşiretinden ${ }^{6}$ Cafer Kulu Han, önemli rol oynadı. Bundan dolayı Feth Ali Şah, Tebriz ve Hoy'un idaresini, Cafer Kulu Han'a verdi. Ancak Cafer Kulu Han bilahare Hoy'da bağımsız bir hanlık kurabilmek gayesiyle isyan etti (Minorsky, 1993: 92). Cafer Kulu Han'ın isyanı üzerine Feth Ali Şah, Güney Azerbaycan'a yürüdü. Şah'ın kendi üzerine geldiğini haber alan Cafer Kulu Han, Hoy'dan kaçarak Osmanl1-İran hududunu aşip, Van Sancağı yakınındaki Hayderanlu aşiretine firar etti. Hoy valiliğine Hüseyin Han'1 tayin eden Feth Ali Şah, bu arada ülkenin güneyinde Fars (Şiraz) valisi kardeşi Hüseyin Kulu Han isyan edince, isyanı bastırmak üzere Güney Azerbaycan'dan ayrıldı. Onun Güney Azerbaycan'dan ayrılmasını ve Hoy valiliğine atadığg Hüseyin Han'ın bu esnada ölümünü firsat bilen Cafer Kulu Han ise, Osmanlı topraklarından topladığı aşiret kuvvetleriyle Hoy’a döndü (Kalantari, 1976: 27 vd). Feth Ali Şah, Dumbuli Cafer Kulu Han'ın üzerine bu defa oğlu aynı zamanda veliahtı Abbas Mirza (Uluerler, 2015: 351) ile serdarı Süleyman Han'ın sevk ve idaresinde güçlü bir ordu sevk etti (Hatt-1 Hümayun, 160/6680-B). Nihayet Hoy yakınlarında Eylül 1799 (Rebiül'ahir 1214)'da yapılan muharebede, Cafer Kulu Han, Abbas Mirza ve serdar Kaçar Süleyman Han'a yenilerek (Kalantari, 1976: s. 29) Bayezid Sancağı Mutasarrıfı, aynı zamanda damadı Mahmud Paşa'nın yanına kaçtı ve Bayezid Sancağı dahilindeki Köroğlu kalesinde ikamet etmeye başladı (Mehmed Ref'i, 1333: 27). İran kuvvetleri, muharebenin akabinde Bayezid Mutasarrıfi Mahmud Paşa'nın Cafer Kulu Han ile "muhabbeti hasebiyle", Osmanl1-İran hududunu geçerek, Bayezid Sancağı'na bağlı bir iki köyü yağmaladı (Hatt-1 Hümayun, 160/6679).

İran tarafından gelerek halihazırda Bayezid Sancağı sınırları içerisinde oturmakta olan sabık Hoy Hanı Cafer Kulu Han, Hacı Taki Bey ismindeki elçisini Erzurum valisi Abdurrahman Paşa’ya

\footnotetext{
${ }^{6}$ Kaynakların ifadesine göre Dumbuli aşiretinin anayurdu, Hoy yakınlarındaki Sökülenabad şehridir. Dumbuli aşireti vaktiyle Safeviler'in İran'da yönetime gelmesinde rol oynadı. Bundan dolayı Şah İsmail(1501-1524), yönetime geldikten sonra, kendisine devletin kuruluşunda yardım eden diğer aşiretlerin yanında Dumbuli aşiretine de ödül olarak, büyük toprak sahaları verdi. Bkz. Aynur Emenova, "Tebriz Hanlığı”, Türkler, c. VII, Ankara 2002, s. 113.

7 Hoy, Güney Azerbaycan'da, meşhur 23 Ağustos 1514 Çaldıran Savaşı'nın yapıldığı Çaldıran Ovası'nın güneydoğusunda yer alan tarihi bir Türk şehridir. Şehir Urmiye'den Kuzey Azerbaycan'a ve Kafkasya'ya, Tebriz'den Trabzon'a giden tarihi ticaret yollarının kavşağını teşkil eder. Hoy şehri hakkında geniş bilgi için bkz. Mirza Bala, "Hoy", M.E.B.I.A., c.V/I, İstanbul 1993, s. 571-573.
} 
göndererek, Osmanlı Devleti'nin bir mahallinde oturabilmek için izin istedi. Ancak onun Osmanlı Devleti'nin topraklarında oturma ruhsatı isteğini, Erzurum valisi Abdurrahman Paşa, o sırada kabul etmedi. Erzurum valisi, Cafer Kulu Han'ın elçisi Hacı Taki Bey'e izin verme gibi bir yetkisinin olmadığını, bunun vazifesinin dışında olduğunu, Dersaadet'ten gelecek emre göre hareket edeceğini beyanla elçiyi geri gönderdi (Hatt-1 Hümayun, 160/6686).

Osmanlı tarafında yukarıda arz ettiğimiz gelişmeler olurken, diğer taraftan İran Hükümeti de, iki devlet arasında bir mesele çıkmaması için Asi Cafer Kulu Han'ın ya Osmanlı topraklarında öldürülmesini veya İran'a geri iade edilmesini veyahut da Osmanlı topraklarından kovulmasını istemekte idi (Hatt-1 Hümayun, 788/36752). Osmanlı Hükümeti, İran Hükümeti’nin talebi karşısında bu ülkeye karşı XVIII. yüzyılın ortalarından itibaren takip ettiği sulh politikasını devam ettirdi. Dolayısıyla 4 Eylül 1746 yılında akdedilen Osmanlı-İran Barış Antlaşması hükümlerine uyarak, mülteci Cafer Kulu Han'a Osmanlı ülkesinde oturma ruhsatı vermediği gibi onu İran Hükümeti'ne geri iade etmeye karar verdi (Hatt-1 Hümayun, 161/6695). Kald1 ki 1746'da imzalanan Osmanl1-İ́ran Antlaşması'nda; sulh antlaşmasının akdedildiği tarihten sonra, İranlılardan Anadolu'ya, Anadolu ahalisinden İran'a gelenlerin himaye edilmeyerek, birbirlerinin vekillerine teslim edilmeleri, bu dostluk ve muhabbetin iki büyük devlet ve iki büyük hanedanın takipçileri tarafından da kalıcı bir şekilde devam ettirilmesi temenni edilmekte idi. ${ }^{8}$ Cafer Kulu Han meselesi hususunda Osmanlı Hükümeti ile İran Hükümeti arasında diplomatik temaslar devam ederken, Cafer Kulu Han'ın Kafkaslar'da sömürge faaliyetlerini iyice arttırarak, Kuzey Kafkasya'dan sonra XIX. yüzyıl başlarında Güney Kafkasya'yı da işgal eden Ruslar'a, 1805’te sığındığı görüldü (Minorsky, 1993: 92). Ruslar, 1806 yılında Cafer Kulu Han'a Şeki'yi tımar olarak verdiler (Minorsky, 1993: 403).

Hoy Hanı Dumbuli Cafer Kulu Han'ın Osmanlı topraklarına ilticası yanında XIX. yüzyıl başlarında Osmanl1-İran siyasi ilişkilerine tesir eden diğer bir önemli amil de Vehhabilerin Kerbela’ya baskınları oldu.

\section{II- Vehhabilerin Kerbela'ya Baskınları ve Osmanlı İran İlişkileri}

İslam dinini, yeni anlayışla katı kurallara bağlayan bir hareket olarak ortaya çıkıp, XVIII. yüzyılın ortalarına doğru siyasi bir mahiyete bürünerek, devam etmiş bir mezhep olan Vehhabilik ${ }^{9}$, Arap Yarımadası'nın Necd bölgesinde zuhur etti.

\footnotetext{
8 “... işbu iki devletin ahali ve reayasından olup, bu akd olunan musalaha tarihinden sonra İran'dan Memalik-i Mahruse'ye ve bu taraftan dahi İran'a firar iden olur ise himayet olunmayup, talep olundukları halde vükela-yı canibeyne teslim olunalar. Ve madem ki şürut-1 mezkureye tarafeynden müra'at olundukça bu musalaha-i hayr-encam ila ma-şaallah sabit ü ber-devam ve ahlaf u a'kab-1 tarafeyn zamanlarında dahi temşiyyet ve istikrarına ihtimam oluna. Bkz. 3 Numaralı Name-i Hümayun Defteri, I. Mahmud-Nadir Şah Mektuplaşmaları, yay. haz. Devlet Arşivleri Genel Müdürlüğü, İstanbul 2014, s. 177.

${ }^{9}$ Bugün Suudi Arabistan'ın resmi mezhebi durumundaki Vehhabiliğin, Arap Yarımadası'ndaki Necd taraflarında kurucusu, Muhammed b. Abdilvehhab (1703-1792)'dır. Vehhabiliğe, Türk tarihinde kendi inançlarında olmayanları küfürle suçlamaları, imanlarındaki taassup ve davranışlarındaki sertlik bakımlarından "Haricilik" hareketi olarak bakılır. Bu yönlerinden dolayı Haricilik ile Vehhabilik arasında bağ kurmak normal karşılanmaktadır.

1703 y1lında Riyad şehrine yakın bir köyde (Uyeyne) doğan Muhammed b. Abdilvehhab ilk tahsilini Uyeyne, Mekke ve Medine'de yaptı. 1740 tarihinden itibaren dini fikirlerini, Necd bölgesinde yayma faaliyetlerine başlayıp, 1744'te Riyad yakınlarındaki Der'iyye'ye geldi. Burada emir Muhammed b. Suud'la bir antlaşma yaptı. Bahse konu antlaşma ile Muhammed $b$. Abdilvehhab, fikirlerini yaymak için sağlam bir maddi güç ve destek bulurken; diğer taraftan Muhammed $b$. Suud da, Muhammed b. Abdilvehhab'ın dini fikirlerinin ortaya koyacağı imkanla siyasi hakimiyetini toprak kazanarak, Arap Yarımadası'na yayma firsatı elde etmiş oldu. Böylece 1744 yılında Vehhabi devletinin temeli resmen olmamakla birlikte atılmış oluyordu.

Muhammed b. Abdilvehhab ve Muhammed b. Suud tarafından başlatılan bu dini-siyasi karakterli hareketin siyasi cephesi, ileriki tarihlerde artarak devam etti. Mamafih Suudlar'ın toprak kazanarak Arap Yarımadası'nda genişleme faaliyetleri, Muhammed b. Suud'un 1766 senesinde ölümünden sonra yerine geçen oğlu Abdülaziz (1766-1803) zamanında da devam etti. Nitekim Abdülaziz, yeni mezhebi silah yoluyla zorla yaymaya çalışarak, çarpışmalarda ele geçirilen ganimetlerin beşte birini kendisine ayırıp, kalanını muharipler arasında paylaştırması, başlatılan hareketi, daha da ilgi çekici hale getirdiğinden taraftarları çoğaldı.
}

Turkish Studies - Historical Analysis

Volume 14 Issue 2, 2019 
XVIII. asrın ikinci yarısından itibaren güçlenmeye başlayan Vehhabiler, aynı asrın sonlarına doğru, doğuda Lahsa, Katif, Bahreyn vs. alarak Basra Körfezi'ne kadar hakimiyet kurdular (Sertoğlu, 2011: 2871; Danişmend, 1972: 80). Vehhabilerin nüfuz bölgelerini genişletmek maksadıyla giriştikleri faaliyetler, XIX. yüzyıl başlarında genişleyerek Devlet-i Aliyye açısından tehlikeli bir hal aldı. Zira Osmanlı devlet merkezinden uzakta olmalarının yanı sıra Sultan III. Selim devrinde Devlet-i Aliyye'nin içeriden ve dışarıdan karşı karşıya kaldığı pek çok gaile ile meşguliyetinden istifade eden Vehhabiler, batıda 1803 'te Taif ve Mekke'yi, 1804 'te de Medine'yi ele geçirdiler. ${ }^{10}$ Daha XIX. asrın başlarında Basra Körfezi'ndeki Res el-Hayme ve Kızıldeniz'deki Cidde, Jambo limanlarından Hindistan ile ticari ilişkiler yürüten (Jorga, 2009: 128) Vehhabiler diğer taraftan cüretlerini daha da arttırarak kuzeyde Osmanlı idari taksimatı içerisinde en ehemmiyetli salyaneli eyaletlerden biri olan Bağdat'1 tehdit etmek suretiyle Irak'a da el atıp, karışıklık çıkardılar.

1800 y1lında Şii Hazail aşiretinin Necef' ${ }^{11}$ ziyaret ettiği sırada, buraya ticaret yapmak için gelen Vehhabiler arasında bir meseleden dolayı tartışma çıktı. Bunlar arasında çıkan kavgada takriben üç yüz civarında Vehhabi, Şii Hazail aşireti mensupları tarafından öldürüldü. Necef'te vuku bulan olaylar, Bağdat'ta duyulunca Bağdat Valisi Süleyman Paşa, kethüdası aynı zamanda damadı Ali Paşa'nın sevk ve idaresinde Necef'e asker sevk etti. Kethüda Ali Paşa, Hazail aşireti mensupları ile Vehhabileri dağıtarak, Necef'teki olayları yatıştırdı (Cevdet Paşa, 1309: 166; Ecer, 2001: 128-129).

Kethüda Ali Paşa, Necef'te düzeni temin etmekle beraber, meselenin kapanmadığ1 görülmektedir. Nitekim Vehhabi lideri, Abdülaziz b. Suud, Necef'teki olayların ardından Bağdat valisi Süleyman Paşa ile temasa geçerek, Necef'te öldürülen Vehhabilerin kan bedellerinin ödenmesini istedi. Bunun üzerine Süleyman Paşa, meseleyi sulh yoluyla halletmek isteyerek Bağdat'in nüfuzlu ailesinden olan Şavi-zade Abdülaziz Bey'i, Abdülaziz b. Suud'a gönderdi. Ancak Vehhabi lideri, isteklerinde 1srar ederek, bu defa da Necef'te öldürülen Vehhabilere kan bedeli olarak Basra taraflarında toprak istedi. Bağdat yönetimi, Abdülaziz b. Suud'un taleplerini reddederek askeri hazırlıklara başladı. Ancak 1801 yılında Kethüda Ali Paşa'nın Vehhabilere karşı yaptığı askeri harekat, susuzluk ve diğer olumsuz sebepler yüzünden başarısızlıkla sonuçlandı (Cevdet Paşa, 1309: 166).

Bütün bu gelişmelerden sonra Vehhabi lideri Abdülaziz, Necef'te Şiilerle vuku bulan tartışma neticesinde Vehhabilerin öldürülmesini bahane ederek, oğlu Suud idaresinde bir askeri kuvveti (ki;

Muhammed b. Abdilvehhab, süslü mezar ve türbelere, bunların kubbelerle örtülmesine şiddetle karşıdır. Nisan 1803 'te Mekke'yi işgal etmelerinin akabinde, Hz. Peygamber (s.a.s.)'in hanımı Hz. Hatice'nin türbesini vb. yıkıp, bunların taşları ile kale yaptılar. Mekke'de Kabe'den ve Makam-1 İbrahim'den başka ne kadar kubbe ve ziyaret yeri varsa hepsini yıktılar. Vehhabilere göre adak adamak, tesbih çekmek, el öpmek bid'attır. Zikir, sünnet ve nafile namazları yasaktır. Yağmur duasına çıkmak günahtır. Hz. Peygamber(s.a.s.)'in hırkasını ve sakalını ziyaret etmek şirktir. Tasavvuf, İslami olmayan bir bid'attır $\mathrm{vb}$.

Vehhabilere göre, Șiilerin Kerbela toprağından yapılma "mühre" üzerine secdeye varmaları, Kabe yerine Meșhed'i ve Necef'i ziyaret etmeleri şirktir. Aşırı Hz. Ali ve ehl-i beyt sevgisi, Hz. Ali evladını masum saymak şirktir. Vehhabiliğin Arap Yarımadası'nda ortaya çıkışı, yayılması ve görüş̧leri hakkında geniş bilgi için bkz. Ethem Ruhi Fığlalı, Çağımızda İtikadi İslam Mezhepleri, İstanbul 1996, s. 96 vd.; keza bkz. Neşet Çağatay, "Vehhabilik”, M.E.B.İ.A., c. XIII, İstanbul 1998, s. 262 vd.; Ahmet Vehbi Ecer, Tarihte Vehhabi Hareketi ve Etkileri, Ankara 2002, s. 51 vd.

10 Abdulaziz'in oğlu Suud, Taif, Mekke ve Medine'yi ele geçirmesini müteakip, halka fevkalade cüretkar bir şekilde, şu şekilde hitap etti: “... sizin dininiz, bugün kemal derecesine erişti. İslam'ın nimetiyle şereflenip, Cenab-1 Hakk’1 kendinizden razı ve hoşnut kıldınız. Artık âbâ ve ecdâdınızın batıl inanışlarına meyl ve rağbetten ve onları rahmet ve hayırla yâd ve zikirden korkun ve kaçının. Ecdâdınız tamamen şirk üzre vefat ettiler..., Hz. Peygamber'in mezarı karşısında, önceleri olduğu gibi durarak, tazîm için salât-u-selâm getirmek, mezhebimizce gayr-i meşrûdur..., Onun için oradan geçenler okumadan geçip gitmeli ve sadece (es-selâmu alâ Muhammed) diye selâm vermelidir...”. Bkz. Eyüb Sabri Paşa, Tarih-i Vehhabiyyan, İstanbul 1296, s. 174-176'dan sadeleştirerek naklen E. R. Fiğlalı, a.g.e., s. 99.

${ }^{11}$ Irak'ta Küfe'nin $10 \mathrm{~km}$ batısında tarihi bir şehir olan Necef'e Hz. Ali’nin şehadet mahalli olmasından dolayı Meşhed de denir. Şehir, Şiilerce kutsal sayılır ve ziyaret edilir. Bkz. Mustafa Öz, "Necef”, T.D.V.İ.A., c. XXXVI, İstanbul 2006, s. 486487. 
bazı kaynakların ifadesine göre 12 bin kişi) Irak'a gönderdi. Suud, Hz. Peygamber'in torunu, Hz. Ali’nin oğlu Hz. Hüseyin'in şehit edildiği yer olması yanında türbesinin de bulunması dolayısıyla Şiilerce kutsal sayılan Kerbela ${ }^{12}$ üzerine yürüdü. Vehhabilerin Kerbela üzerine yürüdükleri esnada Bağdat'ta çıkan veba salgınının devam etmesi ve Vali Süleyman Paşa'nın artık iyice yaşlanması (Cevdet Paşa, 1309: 166-167) nedeniyle Bağdat eyaletinin yönetiminde büyük bir otorite boşluğu yaşanmakta idi.

Vehhabi güçleri, 13 Mayıs 1802 (10 Muharrem 1217) tarihinde Şiilerin matem töreni yaptıkları bir sırada Kerbela'yı basıp, kaynaklarda sayısı iki bin ile beş bin arasında değişen bir Şii topluluğunu öldürerek, şehri yağma ve talan ettiler. Hz. Hüseyin'in mezarını yıkıp, türbedeki altın, gümüş vs. bütün kıymetli eşyaları alarak Der'iyye'ye döndüler (Fasai, 1972: 103; Cevdet Paşa, 1309: 167; Ecer, 2001: 129-130). Bu vahim olay1 Bağdat yönetimi haber alınca, Vali Süleyman Paşa, kethüdası Ali Paşa'yı Kerbela'ya Vehhabiler üzerine gönderdi. Ancak Ali Paşa, Vehhabilerin baskınını müteakip, hemen Kerbela'dan kaçtıkları için bir sonuç alamadı. Bununla beraber Ali Paşa, şehirde bir takım tedbirler aldı. Kerbela'nın etrafını surla çevirme ve hendek kazma faaliyetlerini başlatıp, bölgede yeterli miktarda asker bıraktıktan sonra Bağdat'a döndü. Vali Süleyman Paşa diğer yandan hadiseyi, hem İstanbul'a Bab-1 Ali'ye hem de herhalde olayın İran'da ortaya koyacağı infial ile İran'ın Irak'1 işgal etme ihtimalini dikkate alarak İran Hükümeti'ne de bildirdi (Cevdet Paşa, 1309: 168).

Kerbela'ya Vehhabi baskını İran'da duyulunca büyük bir üzüntü yarattığından İran hükümdarı Feth Ali Şah (1797-1834), Vehhabilerin Kerbela'da katliam yapmalarında Vali Süleyman Paşa'yı suçlayarak, Vehhabilerin cezalandırılmasını istedi. Aksi takdirde Vehhabileri cezalandırmak için Bağdat'1 istila tehdidinde bulundu (Hatt-1 Hümayun, 160/6685; 93/3797-F). Dolayısıyla Osmanl1-İran ilişkileri gerginleşti. Süleyman Paşa, bu durum karşısında, Hz. Hüseyin'in türbesinin tamir edileceğini, Kerbela'nın etrafının surla çevrileceğini, bundan sonra Vehhabi saldırılarına karşı icap eden tedbirlerin alınacağını İran Hükümeti’ne bildirdi (Hatt-1 Hümayun, 93/3797-F).

Öte yandan bu sırada İstanbul'da İngiliz elçisi, Hindistan yolunun güvenliğini temin etmek gayesiyle Bab-1 Ali nezdinde diplomatik temaslarda bulunmaktaydı. İngiliz elçisi ile Osmanlı Hükümeti yetkilileri arasında yapılan toplantıda İngiliz elçisi özetle; Bağdat’tan aldığı istihbarata göre, Irak'ta kargaşa olduğunu, Kerbela baskınından dolayı İran'ın rahatsız olduğunu, baskın hususunda Osmanlı Devleti'ni suçladıklarını, eğer Osmanlı Hükümeti, İran ile sulh yapmak isterse, arabuluculuk yapabileceğini beyanla; Vehhabilerin cezalandırılmasında Osmanlı Devleti ile İran'ın müşterek hareket etmesini önerdi. Osmanlı Hükümeti yetkilileri ise İngiliz elçisine; Osmanlı Devleti ile İran Hükümeti arasında sulhun devam ettiğini, Kerbela'nın çevresine sur yapılmasına, İranlıların $\mathrm{Hz}$. Hüseyin'in türbesini ziyaret etmelerinin yasaklanacağı ve ziyaret parası alınacağını ileri sürerek karşı çıktıklarını, Vehhabilerin cezalandırılmasında, İran ile müssterek hareket edilmesinin Bab-1 Ali'nin dış siyasetine ters düştügünü dile getirerek, Vehhabilerin tenkili için Osmanlı Hükümeti'nin hazırlıklara başladığını, İran Hükümeti’ne bilgi vermek için de bir elçinin İran'a gönderilmesine karar verildiği (Cevdet Paşa, 1309: 171-172) cevabını vererek, İngiliz elçisinin tekliflerine itibar etmedi.

Bağdat yanında Basra, Şehrizor eyaletlerini de yirmi seneden fazla bir süre takdire şayan bir şekilde idare eden ve "Büyük" lakabıyla anılan kölemenlerden ${ }^{13}$ Süleyman Paşa, Ağustos 1802

\footnotetext{
12 Bağdat'ın 100 km Güneybatısında bulunan Kerbela şehri hakkında bkz. E. Honıgman, "Kerbela”, M.E.B.I.A., c. VI, İstanbul 1993, s. 580-582.

13 “... Sultan III. Ahmed(1703-1730) ve Sultan I. Mahmud(1730-1754) devirlerinde otuz yıla yakın bir süre Bağdat Valiliğinde, gücü ve zenginliği dillere destan olmuş olan Hasan Paşa oğlu Ahmed Paşa, pek çok köle satın alıp, bunlardan becerisi ve yeteneği görülenleri, gerek yönetimi altındaki yerlerde gerekse kendi dairesi içinde görevlendirerek Bağdat’ta da bir kölemen hükümeti ortaya çıkmıştı...”. Bkz. Mustafa Nuri Paşa, Netayicül- Vukuat, c. III-IV, sad. Neşet Çağatay, Ankara 1992, s. 99; Irak'ta Kölemen (Memlük)'lerin dönemi, köle kökenli valilerin 1749 y1lından itibaren başa gelmeleri ile başlamış ve 1831 yılında Davud Paşa'nın tutuklanması ile son bulmuştur. Bunların 1517 yılında Yavuz Sultan Selim(15121520) tarafından ortadan kaldırılan Misır Memlük(Kölemen) Devleti ile herhangi bir ilgisi yoktur. Bkz. Sinan Marufoğlu,
} 
(Rebiülahir 1217)'de vefat etti. Yerine Süleyman Paşa'nın vasiyeti üzerine büyük damadı ve kethüdası yine kölemenlerden Abaza Ali Paşa tayin edildi (Sabit, 1292: 21 vd).

XIX. yüzyıl başlarında Osmanl1-İran ilişkilerini etkileyen bir başka faktör, Osmanl1-İran sınırı üzerinde (Kuzey Irak tarafında) yaşayan aşiret ve aşiret beylerinin çıkardığı hadiselerdir.

\section{III- Bilbas Taifesinin Çıkardığı Hadiseler ve Baban Mutasarrıfı Abdurrahman Pașa'nın İran'a Sığınması}

Abaza Ali Paşa'nın Bağdat valiliğine tayin edilmesinden sonra, Kuzey Irak'ta Şehrizor Eyaleti ${ }^{14}$ dahilinde Süleymaniye sancağına tabi Caf-1 Süleymani aşireti taifesinden (Mehmed Hurşid Paşa, 1997: 181) Osmanlı tebaasından oldukları halde kâh Osmanlı topraklarında kalıp, kâh İran topraklarına geçerek, "oraya buraya atılan" ve konargöçer bir hayat süren Bilbas taifesi karışıklıklar çıkardı (Mehmed Hurşid Paşa, 1997: 205, 212). Bilbas taifesinin üzerinde çalıştığımız devrede de Osmanlı topraklarından İran topraklarına geçerek karışıklıklar çıkarması, İran Hükümeti'nin şikayetine yol açtığından, Bağdat valisi Ali Paşa bizzat, Bilbas kabilesinin üzerine yürüdü. Bunları itaat altına alarak Bağdat'a döndü (Cevdet Paşa, 1309: 238). Bu esnada Bağdat'ta iktidar mücadelesi devam ediyordu. Nitekim Ali Paşa, vali olmadan önce de kendisine muhalif olduğu görülen Bağdat'in nüfuzlu ailesinden Şavi-zadelerden Mehmed Bey'i, kardeşi Abdülaziz'i öldürtüp oğullarını hapsettirdi. Ancak Şavi-zade Mehmed Bey'in oğlu Casim Bey, başında bulunduğu El Ubeyd kabilesiyle birlikte kaçarak Habur taraflarına geldi. Rakka valisi Demir Paşa, Casim Bey üzerine yürüdü. Fakat yapılan muharebede Rakka valisi Demir Paşa, yenilgiye uğradı (Cevdet Paşa, 1309: 238). Ali Paşa, 1805 yılı baharında merkezi Süleymaniye kasabası olan Baban sancağ ${ }^{15}$ Mutasarrıfi Abdurrahman Paşa'yı, maiyetine Köysancak ${ }^{16}$ Mutasarrıfı Mehmed Paşa'yı vererek Şavi-zade Casim Bey'in üzerine gönderdi. Ancak Ekrad beyleri kendi aralarında öteden beri devam edegelen rekabet ve nüfuz mücadelesi içinde idiler. O sebeple Şavi-zade Casim Bey üzerine yürüyen Abdurrahman Paşa, rakibi Köysancak Mutasarrıfı Mehmed Paşa'yı, Kerkük yakınlarında öldürüp, Bağdat valisi Ali Paşa'ya bildirdi. Ali Paşa, Abdurrahman Paşa'nın Mehmed Paşa'yı katletmesini tasvip etmemekle beraber, Irak'ın mevcut siyasi durumu nedeniyle, bu olaya tahammül etmek zorunda kaldı. Buna rağmen Abdurrahman Paşa, Ali Paşa'ya karşı itaatsiz hareketlerine devam edince, Bağdat valisi Ali Paşa, Abdurrahman Paşa'yı Baban Mutasarrıflığ görevinden azl etti. Baban Mutasarrıflığına aynı aileden (Baban ümerasından) Ahmed Paşa'nın oğlu Halid Bey'i, öldürülen Mehmed Paşa'nın yerine de Köysancak Mutasarrıflığına, İbrahim Paşa'nın oğlu Süleyman Bey’i tayin etti.

Osmanlı Döneminde Kuzey Irak, İstanbul 1998, s. 37; Bağdat'taki kölemen hükümeti hakkında geniş bilgi için bkz. Sabit, Bağdat'ta Kölemen Hükümetinin Teşekkülü ile İnkırazına Dair Risale, İstanbul 1292, s.1 vd.

14 “...Ş̧ehrizor yahut Şehrizur, Şehrizul Eyaleti, şimalden Musul ve Hakkari eyaletleri araziyle ve garben Diclen nehri ile ve cenuben Bağdat eyaleti ile ve şarkan İran memalikiyle hududdu..., Bu eyalet, Irak dahilinde olmak cihetiyle kadimdenberu, ekser ve evkatda havi olduğu sancakların her birinde mutasarrıf ve mütesellim olmak üzere başka başka Bağdat eyaletine mülhakan, idare olunup bazı vakitlerde dahi eyalet itibar olunarak, vüzera-yı izamdan birinin uhde-i idaresine tefviz ve ihale olunagelmiştir... XIX. yüzyılda ise, Kerkük, Erbil, Köysancak, Süleymaniye, Revandiz ve Harir sancaklarından mürekkeb ve Bağdat valilerinin taht-1 nezaret-i umumiyelerinde başka bir eyalet idi...”. Bkz. Mehmed Hurşid Paşa, Seyahatname-i Hudud, çev. Alaattin Eser, İstanbul 1997, s. 168.

${ }^{15}$ Baban Sancağı(Liva-i Süleymaniye), kuzeyden Köysancak, batıdan Kerkük Sancağı ve Altun Köprü kazası, doğudan İran memalikinden olan Avnaman ve Mihriban(Merivan), Sakız, Hurhure yine İranlu tasarrufunda olup Bane ve Serdeșt nam mahaller ile hudud idi. Bkz. M. Hurşid Paşa, a.g.e., s. 171-172.

XVII. asrın ikinci yarısında ocaklık olarak Baban Sancağı'nın merkezi Kara Cuvalan(Kara Çolan/Kara Çavalan) idi. Bkz. İsmail Hakkı Uzunçarş1lı, Osmanlı Tarihi, c. IV/I, Ankara 1982, s. 458; Şehrizor Eyaletine bağlı Süleymaniye livası eski adıyla Baban Sancağı, “...1267(1850) senesine gelince taraf-1 eşref-i saltanat-1 seniyyeden paşalık ünvanıyla ve bazan mir-i miranlık rütbesiyle yerlüsinden ve Baban oğullarından birer zata ihale olunagelirdi...”. Bkz. M. Hurşid Paşa, a.g.e., s. 174.

${ }^{16}$ Şehrizor eyaletine bağlı Köysancak “... bir taraftan Süleymaniye kazaları ve bir taraftan Erbil ve bir taraftan Revandiz ve bir taraftan Serdeşt ve Lahican nam mahal ile mahdud...” idi. Bkz. M. Hurșid Paşa, a.g.e., s. 203. 
Baban Mutasarrıflığına yerleşmek üzere, Baban Sancağına doğru yürüyen Halid Paşa'nın Abdurrahman Paşa tarafından yolu kesildi. İki taraf arasında çıkan çatışmada Halid Paşa hezimete uğradı. Halid Paşa'nın Abdurrahman Paşa karşısında yenilgiye uğradığını haber alan Ali Paşa, Bağdat'tan Abdurrahman Paşa üzerine yürüyüp, Derbend'de yapılan çarpışmada onu bozguna uğrattı. Halid Paşa'yı Baban Sancağına, Süleyman Paşa'yı da Köysancak'a göndererek Eylül 1805 (Recep 1220)'te Bağdat'a döndü. Derbend'de bozguna uğramasından sonra kaçan Abdurrahman Paşa ise, kendisine bağlı aşiretlerle birlikte Osmanlı-İran sınırını geçerek, İran'a iltica edip, İran Şah'ından yardım istedi (Cevdet Paşa, 1309: 23). Müteakiben Bağdat valisi ile İran Hükümeti arasında diplomatik temaslar başladı. Mamafih Bağdat valisi Ali Paşa, İran hükümdarı Feth Ali Şah'a elçi gönderdi. Ali Paşa, elçisiyle İran Şahı'na gönderdiği mektupta, iki ülke arasında daha önce yapılan sulh şartları gereğince, Osmanlı topraklarında karışıklık çıkararak, İran'a sığınan Kürd Abdurrahman Paşa'nın geri iade edilmesini istedi (Hatt-1 Hümayun, 160/6667). Bunun üzerine Feth Ali Şah da, Bağdat'a bir elçi göndererek, Ali Paşa'nın talebinin aksine Kürd Abdurrahman Paşa'yı himaye ederek, eski görevi olan Baban Mutasarrıflığına tekrar tayin edilmesini istedi (Hatt-1 Hümayun, 2/46).

Ali Paşa, İran elçisi vasıtasıyla verdiği cevapta özetle; Abdurrahman Paşa'nın yaptığı fenalıklardan bahisle, Devlet-i Aliyye ile İran arasında mevcut antlaşma şartlarına göre, tarafların karşılıklı olarak firarileri kabul etmemesi lazım geldiğini, evvelce İran tarafından Osmanlı topraklarına iltica eden Ali Kulu Han'ın antlaşma gereğince, İran'a iade edildiğini, dolayısıyla eşkıya Abdurrahman'ın dahi Osmanlı Devleti'ne geri iade edilmesi gerektiğini İran Hükümeti'ne bildirdi. ${ }^{17}$ Bu arada Tahran'da bulunan firari Abdurrahman Paşa, İran Hükümeti yetkililerine, Bağdat valisi Ali Paşa'nın halen Vehhabi meselesiyle meşguliyeti nedeniyle güç durumda olduğunu, böyle bir esnada İran Hükümeti tarafından her ne teklif edilirse edilsin reddedemeyeceğini şayet Baban Mutasarrıflığı kendisine verilirse, yüklü miktarda mal vereceğini beyan etmek suretiyle Bağdat valisi Ali Paşa aleyhine olumsuz telkinlerde bulunmakta idi (Cevdet Paşa, 1309: 51). Babanlı Abdurrahman Paşa'nın İran başkenti Tahran'da Bağdat valisi Ali Paşa'nın dolayısıyla Osmanlı Devleti'nin aleyhine olumsuz propagandalarını sürdürdüğü esnada, İran hükümdarı Feth Ali Şah, Bağdat'a bir elçi daha gönderdi. İran Şahı bu defa Babanlı Abdurrahman Paşa'ya Baban Mutasarrıflı̆̆ının verilmesine ilave olarak, cüretini daha da arttırarak, sözde hediye-pişkeş adı altında Bağdat valisi Ali Paşa'dan elli bin tümen haraç istedi. İstenilen paranın gönderilmemesi halinde de muharebe ile diğer bir deyişle zorla alınacağ tehdidinde bulundu (Hatt-1 Hümayun, 105/4116). Feth Ali Şah'1n kuzeybatıda Kafkasya cephesinde, İran-Rus Harbinin devam ettiği bir sırada, Osmanlı Devleti'nin bir valisinden haraç isteyerek, Irak'1 istila etme tehdidinde bulunması, Osmanl-İran ilişkileri tarihinde eşine az rastlanan bir tarihi hadisedir.

Osmanlı Hükümeti'nin İran ile mevcut barışı ve dostluğu 1srarla devam ettirme politikası takip etmesine rağmen, İran Şahı'nın öteden beri Osmanlı toprakları dahilindeki Baban Mutasarrıflı̆̆ının Abdurrahman Paşa'ya tekrar verilmesinde israr etmesi yanında Bağdat valisinden haraç isteyerek, Osmanlı Devleti'ne karşı hasmane bir tavır takınması ve Osmanlı topraklarına tecavüz etme tehdidinde bulunması, iki ülke ilişkilerinin önce gerginleşmesine ardından fiili çatışmaya dönüşmesine yol açtı.

\section{IV- İran'ın Tehditleri Karşısında Ali Paşa'nın İran'a Karşı Harekete Geçmesi ve Osmanlı-İran İlişkileri}

İran Hükümeti ile Bağdat valisi Ali Paşa arasındaki diplomatik temaslardan bir netice alınamaması üzerine İran Şahı, Abdurrahman Paşa'yı Baban Mutasarrıflığına tayin edip yanına yardımcı olarak Sinne (Senendeç) valisi Amanullah Han'ın kumandasında asker vererek Baban Sancağına gönderdi. Ayrıca Feth Ali Şah, Kuzey Irak tarafı Osmanl1-İran hududunun muhafazası için,

17 “...İran'la aramızda bulunan muahede mucibince, tarafeyn firarilerinin kabul olunmaması lazım gelüb, evvelce İran'dan bize iltica iden Ali Kulu Han'ın ahd gereğince İran tarafina iade edilmiş olmasına binaen bila-iltimas Abdurrahman eşkiyasının dahi iadesi lazım gelmekde olub...”. Bkz. B.O.A., Hatt-ı Hümayun, D. Nr. 161, G. Nr. 6703. 
oğlu Muhammed Ali Mirza'yı stratejik, askeri, ekonomik öneme sahip Kirmanşah'a ${ }^{18}$ gönderdi (Kalantari, 1976: 41).

Kuzey Irak'ta yukarıda değinilen gelişmeleri Bağdat valisi Ali Paşa haber alınca, hiddetlenerek (ki; kaynaklarda Ali Paşa'nın cesur olduğu kadar, yaratılış itibariyle çabuk kızan, asabi huylu bir vali olduğu ifade ediliyor) böyle bir durum karşısında İran'a karşı nasıl hareket edeceği hususunu, İstanbul'a Bab-1 Ali'ye arz etmeden, diğer bir deyişle Hükümet'in fikrini almadan, İran ile mücadeleye başladı. Haziran 1806 (Rebiülahir 1221)'da sayıs1 12 bini bulan Irak askeri ile Bağdat'tan İran'a karş1 harekete geçti. Mevcut durumu, sefer yürüyüşü esnasında yolda, İstanbul'a bildirdi (Cevdet Paşa, 1309: 51; Uluerler, 2009: 125-126).

Ali Paşa'nın birdenbire Bab-1 Ali'nin herhangi bir emrini almadan İran'a karşı harekete geçmesi, öyle anlaşl1ıyor ki; İran hükümdarı Feth Ali Şah'ın kendisinden hediye adı altında haraç istemesi yanında İran'a sığınan asi bir Osmanlı Mutasarrıfını himaye ederek Osmanlı toprakları dahilinde Kuzey Irak'ta zorla mutasarrıf yapmak üzere harekete geçmesi dolayısıyla Vali'nin Bağdat eyaletini veyahut Irak'1 ani bir İran taarruzuna karşı koruma endişesindendir. Fakat Osmanlı Devleti'nin genel olarak dahili ve harici pek çok mesele ile karşı karşıya kaldığı, İran Devleti'ne karşı sulh politikasını devam ettirmek istediği, üstelik Fransız İmparatoru Napolyon Bonapart'ın teklifiyle, Azerbaycan'a kadar ilerleyen Ruslar'a karşı Fransa, Osmanlı ve İran devletleri arasında üçlü bir ittifak antlaşmasının kurulabilmesi için Seyyid Mehmed Ref'i Efendi'nin sefaretle ${ }^{19}$ İran'a gönderildiği bir devrede Bağdat valisinin Bab-1 Ali'ye durumu arz etmeden İran'a karşı harekete geçmesi, akla yakın bir davranış değildir. Kaldı ki Osmanlı Devleti’nde herhangi bir ülkeye ya da ülkelere karşı sefere çıkmaya başta Padişah olmak üzere, bütün devlet ricalinin katıldığı "meşveret-i azime" (büyük danışma kurulu) karar verirdi (Yıldız, 2006: 21 vd). Dolayısıyla Osmanlı Devleti'nde bir valinin İran'a sefer açma yetkisi yoktu.

Bütün bunlardan sonra Osmanlı Hükümeti, Bağdat valisi Ali Paşa'ya iki devlet arasında mevcut barış ve dostluğu bozacak hareketlerden kaçınmasını, şayet İran üzerine yürüdü ise, emri aldığ 1 yerde geri dönmesini kati surette emretti. Ancak emri İran üzerine yürüdükten sonra yolda alan Ali Paşa, Bab-1 Ali’nin kati emrine rağmen geri dönmeyip, Baban Mutasarrıflığına tayin ettiği Halid Paşa'ya yardım etmek gayesiyle yeğeni ve kethüdası Süleyman Bey'in sevk ve idaresinde İran üzerine asker gönderdi (Cevdet Paşa, 1309: 52). Bu esnada Ali Paşa'nın kontrol edemediği bir kısım aşiret kuvveti, Osmanlı-İran sınırını geçerek Kirmanşah taraflarına akınlar düzenleyip, İran'ın bazı yerlerini yağmaladılar (Uluerler, 2009: 127). Bağdat valisi Ali Paşa'nın kethüdası Süleyman Bey'in kumandasında İran üzerine gönderdiği kuvvetler, İran'a ait Mihriban önlerine kadar ilerledi. Nihayet Mihriban Ovası'nda Muhammed Veli Han, Safiyar Han ve Faracullah Han'ın kumandasındaki üstün İran kuvvetleriyle, Osmanlı kuvvetleri arasında vuku bulan muharebede, Osmanlı kuvvetleri yenilgiye uğradı. Osmanlı kuvvetlerinin komutanı Kethüda Süleyman Bey, İran kuvvetlerine esir düştü (1806).

Mihriban muharebesinin ardından İran kuvvetleri, Osmanlı-İran sınırını geçerek Zohab ve çevresindeki köyleri yağmaladılar. Abdurrahman Paşa ise İran askerlerinin yardımı ile Baban (Süleymaniye) sancağını ele geçirdi (Kalantari, 1976: 44-45). Süleymaniye'ye yerleşen Abdurrahman

\footnotetext{
${ }^{18}$ Kirmanşah, Irak tarafı Osmanlı-İran hududu üzerinde Zağros sıradağlarının kuzeybatısında yer alır. XVI. asır başlarından itibaren aralıklarla uzun yıllar süren Osmanlı-İran savaşları sırasında, pek çok defa Osmanlı Devleti ile İran arasında el değiştiren ve Sultan IV. Murad(1623-1640) zamanında 1630(1039)'da vezir-i azam Hüsrev Paşa tarafindan surları tahkim edilen Kirmanşah'ta, Kaçar Devleti şehzadeleri de yöneticilik yaptılar. Bilhassa 1806-1821 yılları arasında Feth Ali Şah'ın oğlu Muhammed Ali Mirza'nın valiliği döneminde şehrin stratejik ve iktisadi önemi arttı. Şiilerin kutsal merkezleri Kerbela ve Necef'e ziyarete giden Şii hacıların Kirmanşah’tan geçmeleri şehrin ekonomik gelişmesine katkıda bulundu. Bkz. Marcel Bazın, "Kirmanşah", T.D.V.I.A., c. XXVI, Ankara 2002, s. 66-67.

${ }^{19}$ Seyyid Mehmed Ref'i Efendi'nin İran Sefaretnamesi hakkında bkz. “İran Sefaretnamesi”, T.O.E.M., S. 43-44, İstanbul 1333, s. 1-31.
} 
Paşa, mutasarrıflığını tasdik ettirmek için, Bağdat valisi Ali Paşa’ya müracaat ederek, suçunun bağışlanmasını istedi (Cevdet Paşa, 1309: 52).

Bab-1 Ali'nin İran ile sulhu korumak maksadiyla Abdurrahman Paşa'ya Baban Mutasarrıflığının verilmesi hususunda emrini (Hatt-1 Hümayun, 161/6704) alan Ali Paşa, Abdurrahman Paşa'yı affedip, onu yeniden eski görevi olan Baban Mutasarrıflığına tayin etti. ${ }^{20}$ Diğer taraftan Osmanlı Hükümeti, Mihriban muharebesinde İran kuvvetlerine esir düşen Kethüda Süleyman Bey'i ve diğer Osmanlı esirlerini esaretten kurtarabilmek için Erzurum valisi Ziya Paşa vasıtasıyla harekete geçti. Erzurum valisi Ziya Paşa, Tebriz valisi Feth Ali Şah'ın oğlu, aynı zamanda veliahdı Abbas Mirza aracılığı ile İran Hükümeti ile diplomatik temasa geçti. İran Hükümeti, Erzurum valisinin taleplerine müspet cevap verip, Kethüda Süleyman Bey ve diğer Osmanlı esirlerini serbest bırakarak Bağdat'a gönderdi (Hatt-1 Hümayun, 3/86).

Osmanlı Hükümeti'nin 1806 Osmanlı-Rus-İngiliz harbi arifesinde şark hududunda (Kuzey Irak) asi bir mutasarrıfın İran'a iltica ederek, iki devleti fiili çatışmaya götürecek kadar meşgul etmesine rağmen onu affederek eski görevine yeniden tayin etmesi ve meseleyi sulh yoluyla halletmesi oldukça dikkat çekicidir. Esasen asi devlet görevlilerini affetmek suretiyle yeniden göreve getirerek meseleyi halletmek, Osmanlı Devleti'nin öteden beri zaman zaman başvurduğu yöntemlerden biridir. ${ }^{21}$ Zira Kuzey Irak'taki Baban ümerası, Bağdat valilerine bazen tabi olurlar, Osmanlı ordusuyla bir olup, İran'a karşı savaşırlar bazen de Osmanlı Devleti'ne isyan ederek İran Devleti'nin hakimiyetini tanırlardı. Bütün mesele Bağdat valilerinin onları dirayetle idare edebilmesindeydi. Onun için Osmanlı Hükümeti'nin kaynaklardan anlaşıldığı kadarıyla İran Hükümeti'nin himaye ettiği asi Abdurrahman Paşa'nın Baban Sancağı Mutasarrıflığına yeniden tayin edilmesinde İran'a taviz vermeyip, aksine Aralık 1806 yılında başlayan Osmanlı-Rus, İngiliz savaş1 öncesinde, stratejik olarak, şark hudutlarını en azından emniyete aldığı söylenilebilir.

\section{Sonuç}

İran'da 1779 yılında başlayan iktidar mücadelelerine son vererek, XVIII. yüzyılın sonlarına doğru Kaçar Türkmen Devleti (1795-1925)'ni kurmak suretiyle bu ülkede siyasi birliği yeniden tesis eden Ağa Muhammed Han (1795-1797) oldu. Onun Haziran 1797'de öldürülmesini müteakip İran şahlığına, yeğeni Feth Ali Şah (1797-1834) geçti. Feth Ali Şah'ın uzun süren iktidarının ilk yıllarında Osmanlı tahtında Sultan III. Selim (1789-1807) bulunuyordu. Bu iki hükümdar zamanında yahut XIX. asrın tam başlarında, İngiltere, Fransa ve Rusya gerek Osmanlı ülkesinde gerekse İran'da nüfuzlarını giderek arttırdı. Her iki devlet de sömürgeci Avrupa devletleriyle ilişkilerinde, bunlardan bazen birine bazen de diğerine dayanarak denge politikası takip etmek zorunda kaldı.

XIX. yüzyıl başlarında Osmanlı-İran ilişkilerinde, İran'ın Hoy Hanı'nın Osmanlı Devleti'ne iltica etmesi, Kuzey Irak'ta Osmanlı tebaasından Baban Mutasarrıfinın da İran'a sı ğınması ve Vehhabilerin Kerbela'yı basmaları ile Bağdat valisi Abaza Ali Paşa'nın Osmanlı Hükümeti’nin hiçbir emrini almadan İran'a karşı harekete geçmesi hadiseleri etkili oldu.

İran'dan Osmanlılar'a sığınan Hoy Hanı ile Osmanlı topraklarından İran'a kaçan Baban Mutasarrıfı, yönetici olmaları yanında aynı zamanda aşiret beyi idiler. Osmanlı-̇̇ran hududu üzerindeki aşiret beylerinin Osmanl1-İran sınırını ihlal ederek, kâh İran, kâh Osmanlılar tarafina geçmeleri ve diğer firar olayları ile ilgili olarak, iki devlet arasında 4 Eylül 1746'da imzalanan antlaşmada, firarilerin karşılıklı olarak taraflara geri iade edilmesi hususunda kati hüküm bulunmasına

\footnotetext{
20 “...firari Abdurrahman Paşa'nın afvı ile yerine ikad edildiği, İran tarafına bildirilmekle, Devlet-i Aliyye ile İran arasında müveddet ve müsalemetin baki olduğu...”. B.O.A., Hatt-ı Hümayun, D. Nr. 161, G. Nr. 6717.

${ }^{21}$ Mesela XVII. yüzyılın ilk yarısında iki defa isyan ederek devleti, müşkül duruma sokan, vezir-i azam ve serdar-1 ekrem Hüsrev Paşa karşısında zor duruma düşünce de İran Şah'1 I. Abbas'a müracaat eden Erzurum valisi Abaza Mehmed Paşa'yı Sultan IV. Murad(1623-1640), 1628 yılında affederek, Bosna valiliğine tayin etmişti. Bkz. İsmail Hakkı Uzunçarşılı, Osmanlı Tarihi, c. III/I, Ankara 1983, s. 151 vd, 164 vd.
} 
rağmen meselenin halledilemediği, dolayısıyla sınır ihlallerinin XIX. yüzyıl başlarında da devam ettiği anlaşılmaktadır.

Vehhabilerin 1802'de, Osmanlı toprakları dahilindeki Kerbela'yı basmaları, Vehhabiliğin güçlendiğini ve gün geçtikçe güneyden Osmanlı Devleti için bir tehdit unsuru haline geldiğini göstermektedir. Bununla beraber Osmanlı Hükümeti, İran'la ilişkilerinde Irak'taki Şiilerin kutsal merkezlerinde icap eden tedbirleri aldığından bu meselenin sulh yoluyla halledildiği görülmektedir. Bağdat valisi Ali Paşa'nın Bab-1 Ali'nin herhangi bir emrini almadan Osmanlı-Rus, İngiliz Harbi (Aralık 1806) arifesinde İran'a savaş açması, artık Osmanlı merkezi otoritesinin iyice zayıfladığını, Osmanlı idari taksimatı içerisinde, salyaneli eyaletlerden en önemlilerinden biri olan Bağdat'ta büyük bir otorite boşluğunun yaşandığını ortaya koymaktadır. Ayrıca XIX. yüzyıl başlarında Osmanlı Hükümeti'nin İran ile alakalı meseleleri, Osmanl1-İran hududu üzerindeki eyalet valilerine havale ettiği hatta bazı hudut valileri arasında husumet olduğu dahi gözlemlenmektedir.

Buraya kadar yaptığımız bu kısa değerlendirme göz önüne alınacak olursa, XIX. yüzyıl başlarında Osmanlı-İran siyasi ilişkileri, sınır bölgesinde vuku bulan olaylar sebebiyle zaman zaman gerginleşmiş hatta bir ara fiili çatışmaya dönüşmüşse de, genel itibariyle Osmanlı ve İran hükümetleri, aralarındaki husumete yol açan meseleleri, sulh yoluyla halletmeye çalışmışlardır. Özellikle Osmanlı Hükümeti’nin meselelerin çözümünde, iki ülke arasında daha evvel yapılan antlaşmalara sürekli vurgu yapmak suretiyle İran Devleti ile ilişkilerin bozulmamasına azami gayret sarf ettiği müşahede edilmektedir. Devrin Osmanlı devlet adamlarının Eylül 1746'da yapılan antlaşma ile başlayan sulh sürecinin devamı yönünde bir strateji takip etmelerinin fevkalade makul ve isabetli olduğu kanaatindeyiz.

Kısaca XIX. yüzyıl başlarında Osmanlı-İran ilişkilerinde, Osmanlı Devleti’nin içeride karşılaştığı siyasi, iktisadi, askeri vs. meselelerin yanı sıra dışarıda batı cephesinde hasmı Fransa, İngiltere ve Rusya ile meşguliyeti, diğer taraftan İran Devleti'nin de, bu sıralarda Güney Kafkasya'da Ruslarla harp halinde olmasının etkili olduğu, açıkça görülüyor.

\section{KAYNAKCA}

\section{Bașbakanlık Osmanlı Arşivi Vesikaları}

B.O.A., Hatt-1 Hümayun, D. Nr. 161, G. Nr. 6700.

B.O.A., Hatt-1 Hümayun, D. Nr. 160, G. Nr. 6680B.

B.O.A., Hatt-1 Hümayun, D. Nr. 160, G. Nr. 6679A.

B.O.A., Hatt-1 Hümayun, D. Nr. 161, G. Nr. 6720.

B.O.A., Hatt-1 Hümayun, D. Nr. 161, G. Nr. 6721F.

B.O.A., Hatt-1 Hümayun, D. Nr. 160, G. Nr. 6679.

B.O.A., Hatt-1 Hümayun, D. Nr. 160, G. Nr. 6686.

B.O.A., Hatt-1 Hümayun, D. Nr. 788, G. Nr. 36752.

B.O.A., Hatt-1 Hümayun, D. Nr. 161, G. Nr. 6695.

B.O.A., Hatt-1 Hümayun, D. Nr. 160, G. Nr. 6685.

B.O.A., Hatt-1 Hümayun, D. Nr. 93, G. Nr. 3797F.

B.O.A., Hatt-1 Hümayun, D. Nr. 160, G. Nr. 6667. 
B.O.A., Hatt-1 Hümayun, D. Nr. 2, G. Nr. 46.

B.O.A., Hatt-1 Hümayun, D. Nr. 161, G. Nr. 6703.

B.O.A., Hatt-1 Hümayun, D. Nr. 105, G. Nr. 4116.

B.O.A., Hatt-1 Hümayun, D. Nr. 161, G. Nr. 6704.

B.O.A., Hatt-1 Hümayun, D. Nr. 161, G. Nr. 6717.

B.O.A., Hatt-1 Hümayun, D. Nr. 3, G. Nr. 86.

Name-i Hümayun Defteri, nr. 3 (I. Mahmud-Nadir Şah Mektuplaşmaları), yay. haz. Devlet Arşivleri Genel Müdürlüğü, İstanbul 2014.

Vekayi'nameler ve Telif Eserler

Ahmed Cevdet Paşa, (1309). Tarih-i Cevdet, c. VII-VIII, Matbaa-i Osmaniye, İstanbul.

Aka, İ., (2002). "Selçuklu Sonrası Orta Doğu'da Türk Varlığı”, Türkler, c. VI, s. 839-860.

Bala, M., (1993). "Hoy”. M.E.B.I.A., c. V/I, s. 571-573.

Bazın, M., (2002). "Kirmanşah”, T.D.V.I.A., c. XXVI, s. 66-67.

Beydilli, K., (2009). "Selim III”, T.D.V.I.A., c. XXXVI, s. 420-425.

Çağatay. N., (1988). "Vehhabilik", M.E.B.I..A., c. XIII, s. 262-269.

Danişmend, İ. H., (1972). İzahlı Osmanlı Tarihi Kronolojisi, c. IV, Türkiye Yay., İstanbul.

Ecer, A. V., (2001). Tarihte Vehhabi Hareketi ve Etkileri, Asam Yay., Ankara.

Emenova, A., (2002). "Tebriz Hanlığı”, Türkler, c. VII, s. 113-122.

Fasai, H., (1972). History of Persia Under Qajar Rule Translated from the Persian of Hasan-e Fasai's Farsnama-ye Naseri, Heribert Busse (Çev.), Newyork/London.

Fığlalı, E. R., (1996). Çağımızda İtikadi İslam Mezhepleri, Selçuk Yay., Ankara.

Honıman, E., (1993). "Kerbela”, M.E.B.I.A., c. VI, s. 580-582.

Jorga, N., (2009). Osmanlı İmparatorluğu Tarihi, c. V, Nilüfer Epçeli (Çev.), Yeditepe Yay., İstanbul.

Kalantari, Y., (1976). Feth Ali Şah Zamanında Osmanl-İran Münasebetleri, (Yayımlanmamış Doktora Tezi) İstanbul Üniversitesi/Edebiyat Fakültesi Son Çağ Tarihi Kürsüsü, İstanbul.

Marufoğlu, S., (1998). Osmanlı Döneminde Kuzey Irak, Eren Yay., İstanbul.

Karal, E. Z., (1983). Osmanlı Tarihi, c. V, TTK Yay., Ankara.

Mehmed Hurşid Paşa, (1997). Seyahatname-i Hudud, Alaattin Eser (Çev), Simurg Yay., İstanbul.

Minorsky, V., (1993). "Şeki”, M.E.B.I.A., c. XI,s. 401-404.

Minorsky, V., (1993). "Tebriz”, M.E.B.I.A., c. XII/I, s. 82-98.

Mustafa Nuri Paşa, (1992). Netayücül-Vukuat, c. IIII-IV, Neşet Çağatay (Sad.), TTK. Yay., Ankara.

Öz, M., (2006). “Necef”, T.D.V.I.A., c. XXXVI, s. 486-487.

Pekravan, E., (1951). A $\breve{g} a$ Muhammed Han Kacar, Tahran.

Perry, J. R., (1988). “Aga Mohammad Khan Qajar”, Encyclopadia Iranica, c. I, s. 602-605.

Razi, A., (1375). Tarih-i Kamil-i İran, İkbal Yay., Tahran. 
Sabit, (1292). Bağdat'ta Kölemen Hükümeti'nin Teşekkülü ile İnkırazına Dair Risale, Vakit Yay., İstanbul.

Sertoğlu, M., (2011). Mufassal Osmanlı Tarihi, c. V, TTK Yay., Ankara.

Seyyid Mehmed Ref'i Efendi, (1333), "İran Sefaretnamesi”, T.O.E.M., S. 43-44, s. 1-31.

Sümer, F., (1988). “Ağa Muhammed Şah”, T.D.V.I.A., c. I, s. 455-456.

Sykes, P. M., (1915). History of Persia, c. II, London.

Uçarol, R., (2000). Siyasi Tarih (1789-1999), Filiz Yay., İstanbul.

Uluerler, S., (2009). XIX. Yüzyılın İlk Yarısında Osmanlı-İran Siyasi İlişkileri, (Yayımlanmamış Doktora Tezi), Fırat Üniversitesi/Sosyal Bilimler Enstitüsü, Elazığ.

Uluerler, S., (2015). "Osmanl1-İran Sınır Tespiti Tartışmalarında Kotur'un Yeri (1849-1852)”, Turkish Studies - International Periodical For The Languages, Literature and History of Turkish or Turkic Volume 10/5 Spring 2015, p. 329-356, ISSN: 1308-2140, www.turkishstudies.net, DOI Number: http://dx.doi.org/10.7827/TurkishStudies.8080, ANKARA-TURKEY

Uzunçarşıl1, İ. H., (1983). Osmanlı Tarihi, c. III/I-IV, TTK Yay., Ankara.

Uzunçarşı11, İ. H., (2010). Meşhur Rumeli Ayanlarından Tirsinikli İsmail, Yılık Oğlu Süleyman Ağalar ve Alemdar Mustafa Paşa, TTK Yay., Ankara.

Yazıc1, T., (1995). "Feth Ali Şah", T.D.V.I.A., c. XII, s. 451-452.

Yıldız, H., (2006). Haydi Osmanlı Sefere, Türkiye İş Bankası Kültür Yay., İstanbul. 